Divan Edebiyatı Araştırmaları Dergisi 5, İstanbul 2010, 1-34.

\title{
Nâbi'nin Şiir ve Diğer Edebî Konular Hakkındaki Görüşleri \\ ÂDEM CEYHAN*
}

Nâbî's views on poetry and other literary genres
Ö Z E T

Bilindiği gibi, divan şairlerinden pek az bir kısmı şiir sanatı ve diğer edebî tür yahut konularla ilgili düşüncelerini divanlarının önsözünde anlatır. Divan sahibi şairlerin çoğu ise manzumelerinde değişik vesilelerle şiir sanatı, kendilerinin bu sanattaki kabiliyeti ve diğer şairler hakkındaki fikirlerini dile getirirler. Sanatkârların şiir ve diğger edebiyat meselelerine ait görüşlerini sadece divanlarinın önsözünde yahut içindeki manzumelerde değil, mensur eserlerinde ve mesnevîlerinde de anlattıklarına rastlanabilmektedir.

$B u$ makalede ünlü divan şairlerinden Nâbồnin şiir ve diğer edebî konular hakkındaki görüşleri esas itibarılyle Hayrî-nâme'nin, vezinli sözün güzelliğinden bahseden bölümüne dayanilarak tesbit ve izah edilmektedir. Nâbî, nazım, nesir, Arap, Fars ve Türk dilleri ile bu uluslarm edebiyatları hakkındaki düşüncelerini, Hayrî-nâme'den başka, Türkçe Dîvâninda ve diğer eserlerinde de zaman zaman ifade eder. Bu yazıda onun Hayriyye'nin anılan bölümünde toplu hâlde ve diğer eserlerinde dağınık şekilde bulunan edebî görüşlerinin birlikte ele alınıp incelenmesi ve poetikasının ortaya konulması hedeflenmektedir.
A N A H T A R K E L İ M E L E R

Nâb̂ิ- Hayrî-nâme, şiir, hikemî şiir, poetika, Arapça, Farsça, Türkçe.

\section{A B S T R A C T}

It is known that a few poets in classic literature expressed his/her own opinions on poetry and other literary genres. Majority of the divan, the book of classical poets, owners gave some information about the art of poem, their own talents in their art and ideas about other poets. The opinions of classical men of letter and artists considered poems and literary issues can be coincided within poets' proses and in their mathnawis (mesnevi) alongside with their divans' preface or in proses taking places in their divans.

In this study the opinions of well-known poet Nabi's poetry and other literary matters are determined and explained by relying on Hayri-name's one chapter where the beauty of metrical word is expressed. Nabi in his Hayri-name expresses his ideas about verse and prose, Arabic, Persian and Turkish languages and literatures in his Turkish Divan and other works from time to time. Here the opinions of Nabi about art, poem, poet, and talent taking place are examined and his poetica is introduced.

\section{K E Y W O R D S}

Nabi, Hayri-name, poem, poet, art, poetica, Arabic, Persian, Turkish.

Bilindiği gibi, Urfalı Nâbî Yûsuf Efendi (Hicrî 1052-1124/ Milâdî 1642-1712), sadece 17. asrın ikinci yarısı ve 18. asır başlarının büyük şairlerinden biri değil, aynı zamanda bütün klâsik Türk edebiyatının

\footnotetext{
* Prof. Dr., Celal Bayar Üniversitesi Fen-Edebiyat Fakültesi Türk Dili ve Edebiyatı Bölümü, Manisa. (ceyhanadem@hotmail.com)
} 
Fuzûlî, Bâkî, Nef'î, Nedîm ve Şeyh Gālib gibi üstadları arasında yer alan bir edebî şahsiyettir. O, bir-iki eseriyle meşhur sanatkârlara nazaran oldukça verimli sayllabilecek; manzum, mensur on eser sahibi bir şair ve yazardır. Türkçe şiirlerinin yer aldığı Dîvânı (Bilkan 1997), Nâbî'nin en fazla tanınan ve sevilen eserlerinden biridir. Gerçi -Muallim Nâcî́nin de ifade ettiği gibi- Nâbî'nin "Zamânımızda memnûniyetle mütalâa olunamayacak pek çok sözleri de vardır" (Muallim Nâcî 1308: 314); fakat asırlardır beğenilerek okunan, yazılan, tanzir, tahmis, tedkik, tahlil ve tehzil edilen hayli şiirlerin, atasözü gibi tanınan nice beyit ve berceste mısraların sahibi olduğu da inkâr edilemez bir gerçektir. Şuara tezkirelerini dolduran yüzlerce divan şairinden bazen güzel bir beyit veya berceste mısranın bile sonraki asırlara kalıcı olmadığı düşünülürse, bunun küçümsenemeyecek bir başarı olduğu herhâlde daha iyi anlaşılabilir. Edebiyatımızda hikemî ve talimî (didaktik) şiirin başta gelen temsilcilerinden olan Nâbî̀nin Arap harfleriyle basılmış Türkçe dîvânı sonunda Farsça gazellerini ve Mevlânâ, Hâfız-ı Şîrâzî, Molla Câmî, Sultan Selim, Feyzî-i Hindî... gibi şairlerin gazellerine yazdı̆̆ tahmisleri içine alan bir Farsça Dîvançesi de vardır (Nâbî 1292/1875: 1-27).

Nâbî Efendi'nin 1113 (1701) yılında, yedi yaşındaki oğlu Ebü’l-hayr Mehmed'e hitaben yazdığı Hayrî-nâme ise, onun divanıla birlikte tanınan ve sevilerek okunan eserlerinden, mesnevi nazım şeklinin ve nasihat-name türünün güzel örneklerinden biridir (Nâb̂̂ 1292/1875: 2-61; Pala 1989; Kaplan 1995). Yaşlı, gün görmüş, hayırhah ve bilge bir babanın, sevgili oğlunun sağlık, esenlik ve saadetini hedefleyerek verdiği dinî, ahlâkî, meslekî tavsiyelerle dolu olan bu eser (Özü ve topluca değerlendirilmesi konusunda, Kocatürk 1964: 460-62), devrinin siyasî, iktisadî ve kültürel manzarasını aksettirmesi bakımından tarihî vesika değerini de taşır (Kortantamer 1984: 83-116). Şairin Hayrâbâd adında, 18. asır sonlarında edebî mahfillerde âdeta benzerinin yazılmasına ihtimâl verilemeyecek kadar övülen bir mesnevisi daha vardır (Mustafa Nihat 1936: 41-43; Mengi 1998: XVII/54-55). Ancak bu eserin sonraki asırlarda Hayrî-nâme kadar rağbet ve şöhrete eriştiğini söylemek zordur. Anılan eseri bilindiği gibi Şeyh Gâlib, Hüsn ü Aşk isimli mesnevisinin sebeb-i te'lîf kısminda çeşitli yönlerden tenkit etmiştir ki söz konusu bahis, edebiyat tarihimizde şumûllü edebî tenkidin bilinen eski örneklerinden biridir (Doğan 2006: 54-65). Nâbî, bazı selefleri gibi, Abdurrahmân-1 
Câmî'nin (H. 817-898/M.1414-1492) Farsça kırk hadis tercümesini aynı aruz kalıbı ve nazım şekliyle dilimize tercüme etmiş (Necîb Âsım 1331/1915: II/143-165; Karahan 1954: 230-32; Sevgi 2000; Korkmaz 2001: I/449-464); ayrica Sultan IV. Mehmed'in şehzadeleri Mustafa ve Ahmed'in 1086 (1675) yılında yapılan sünnet dügüülerini tasvir eden manzum bir Sûr-nâme meydana getirmiştir (Levend 1944; Arslan 1999: 625684).

Nâbî Efendi, saydığımız manzum eserlerden başka değerli mensur eserler de telif etmiştir: Hac seyahat hatıra ve intibalarını anlatan Tuhfetü'l-Harameyn'i, hac farizasını yerine getirmek üzere kafile hâlinde yaptıkları uzun seyahati, ziyaret ettikleri mabedleri, kabirleri ve mukaddes beldeleri oldukça süslü bir nesirle tasvir eden bir metindir (Coşkun 2002). Nâbî'nin, seleflerinden Alaşehirli Veysî’nin (969-1037/1562-1628) sanatkârâne bir üslûpla meydana getirdiği Dürretü't-tâc fî sîreti sâhibi'lmi' râc adlı siyerine iki zeyl yazdığı da bilinmektedir (Erkan 1994: X/3334). Fetihnâme-i Kamaniçe ise Kamaniçe kalesinin 1083 (1672) yılında feth edilişini anlatan, içinde manzumeler de yer alan bir eserdir (Yüksel, 1997). Sanatkârımızın resmî kişilere ve dostlarına yazdığı mektupların derlenmesi suretiyle meydana getirilen bir de Münş̧eât' 1 vardır.

Edebiyat tarihimizin bu ünlü ismine ait eserleri kısaca andıktan sonra asıl konumuza, Nâbî'nin şiir, şiir çeşitleri ve diğer edebî türler hakkındaki görüş ve tavsiyeleri bahsine geçebiliriz. Bilindiği gibi, bazı divan şairlerimiz, umumî olarak şiir sanatına, kendilerinin ve başkalarının şiirlerine dair fikirlerini, değerlendirmelerini divanlarının mensur veya manzum başlangıçlarında ifade etmişlerdir (Üzgör 1990). Nâb̂̂ Dîvânı'nda da şairin şiirlerinin ikinci defa tertip ediliş sebebi konusunda bir manzumesine rastlanır (Bilkan 1997: I/450-52). Onun sadece burada değil, gazel, kaside, rubaî gibi çeşitli nazım şekilleriyle yazdığ1 şiirlerinde de kismen veya tamamen (Bilkan 1997: I/450; II/828-29, 875, 1060) sanat, edebiyat, dil meselelerine ait düşüncelerini ifade ettiği görülür (Erkal 2009: 247-280).

Şüphesiz ki edebiyat tarihimizde yer tutan edebî şahsiyetler, şiire dair fikirlerini sırf divanlarının başındaki dibacelerde veya içindeki çeşitli manzumelerde değil, başka eserlerinde de ifade edebilmektedir. Meselâ, 16. asrın tanınmış edebî şahsiyetlerinden Kastamonulu Latîfî 
(895-990/1490-1582), Tezkiretü'ş-şuarâ'sının baş tarafında vezinli sözün faziletinden, hikmetli şiir meydana getiren şairlerin meziyetinden ve şiir söyleyiş sebeplerinden uzun uzadıya bahsettiği gibi (Canım 2000: 74-83), "Fânî" mahlasını kullanan Filibeli şair Hoca Îsâ'nın, şakirdlerine şiir söyleme adabı konusundaki bazı dikkate değer nasihatlarını da nakleder (Canım 2000: 417-421). Nev'̂̂ Yahyâ (940-1007/1533-34-1599), söz konusu sanata ait kanaatlerini, bu sanatın millî tarih ve kültürümüzdeki yerini Sadrazam Sinan Paşa'ya yazdığı ders verici bir mektupla (Nev'î-zâde Atâî 1268/1852: 424-25; Kortantamer 2004: 178-189), Müstakimzâde Sâdeddîn Süleyman Efendi (1131-1202/1719-1788) ise Şerh-i Dîvân-ı Alî isimli eserinin sonunda (Müstakimzâde Saâdeddin Süleyman 1255/1839: 593-94) ve edebiyat terimleriyle alâkalı bir kitapçı̆̆ının baş taraflarında anlatmıştır (Tolasa 1986: 363-371).

Bazı nasihat-namelerde de şair veya yazarın şiir, methiye, mersiye, mizah, hiciv gibi edebî tür veya konular hakkındaki fikir ve öğütlerini dile getirdiğine zaman zaman rastlanmaktadır. Meselâ, Keykâvus'un H. 475 (M. 1082 yahut bazı nüshalara göre 473/1080) yılında oğlu Giylânşah için yazdığı Farsça nasihat-namenin bir bölümünde şiir sanatı hakkındaki düşünce ve tavsiyelerini ifade ettiğini biliyoruz (Gökyay 1974: 252-56). ${ }^{1}$

Divanında türlü vesilelerle -elbette kendi hayat anlayışına ve yaşayış tarzına göre- şiirin nasıl olması ve olmaması lâzım geldiğini anlatan Nâbî Efendi, oğlu için yazdığı nasihat-namede bu sanata müstakil bir bölüm ayırmış; bahis konusu hünerdeki maharetinin sırlarını da dolaylı olarak açıklamıştır. Bilindiği gibi, Nâbî'nin Hayri-nâme'sinde vezinli sözün güzelliğinden bahseden bir bölüm vardır. Bu bahis, usta şairin edebî görüşlerini, bilhassa şiir sanatı hakkındaki düşünce ve tavsiyelerini oldukça derli toplu bir şekilde ihtiva etmektedir. Nâbî'nin nasihat-namesinin işaret ettiğimiz bölümüne ilâveten diğer eserlerindeki kısmî temasları da mütalâa edildiğinde, poetikası konusunda bir hayli bilgi ve fikir edinmek mümkün olmaktadır. Biz burada onun Türkçe Dîvân, Hayrî-nâme gibi eserleri başta olmak üzere, yeri gelince Tercüme-i Hadîs-i

\footnotetext{
${ }^{1}$ Keykâvus'un bu konudaki bazı fikir ve telkinleriyle Nâbî'ninkiler arasında yer yer benzerlik bulunduğunu da parantez içinde belirtmekte fayda var).
} 
Erbaîn gibi metinlerine de dayanarak şiir; Türk, Arap ve Fars edebiyatı, Arap, Fars, Türk dilleri hakkındaki düşüncelerini, şiirle hikmet, edebî sanatlar ve mana arasındaki münasebet, nazım-nesir mukayesesi, daha sonra hiciv konusundaki fikir yahut tavsiyelerini inceleyip değerlendirmeye çalışacağız. Nâbî'nin söz konusu manzum eserlerinin tedkiki sonucunda şu soruların cevaplarını almış olacağız:

1- Nâbî, şiir sanatı konusunda sevgili oğluna, dolayısıyla diğer okuyuculara ne gibi tavsiyelerde bulunuyor?

2- Ebu'l-hayr Mehmed'in önceki Osmanlı şairlerinden hangilerini okumasını tavsiye ediyor? Fars şairleri hakkında neler düşünüyor ve onlardan hangilerinin okunmasını istiyor? Bundan başka, Arap şairlerinin eserleri konusunda hangi fikirleri ifade etmektedir? Arapça şiirlerin okuyanda ne gibi duygu ve heyecanlar uyandırdığı kanaatindedir? Bahis mevzuu Arapça şiir türlerinden bilhassa hangilerini okunmaya ve tavsiyeye lâyık görmektedir?

3- Şairimizin Arapça, Farsça ve Türkçe hakkındaki düşünceleri nelerdir? Sanatkâr, Arapça öğrenilmesi ve öğretilmesi konusunda hangi telkinlerde bulunmaktadır?

4- Nâbî, şiirin nasıl olması, hangi vasfı taşıması gerektiğini belirtiyor? Onun bu düşüncesinin kültürel dayanakları neler olabilir?

5- Şair, vezinli, kafiyeli fakat içi boş, süssüz, sanatsız ve yeni bir mana taşımayan manzumeler hakkında neler ifade etmektedir?

6- Sadece sevgilinin saçı, boyu, yüzü ve gözünden, gülden, bülbülden, içki ve kadehten bahseden ham şairlerin şiirleri hakkında neler düşünmektedir? Bu, asırlardır devam edegelen şiir geleneğine, şiirlerde çoklukla işlenen konulara karşı bir itiraz ve direniş sayılabilir mi?

7- Nâbî Efendi, manası olmayan ve cinas, îham gibi çeşitli edebî sanatların kullanılmadığı manzumeleri nelere benzetmektedir? Sanatkâra göre, şiir, nasıl olmalıdır?

8- Şair, nesir ve nazmı mukayese ederken, nazmın hangi üstünlügüne temas etmektedir?

9- Sanatkâr, hiciv türündeki şiirler hakkında neler düşünmekte ve bu konuda oğluna ne gibi telkinlerde bulunmaktadır? 
Onun şiir sanatı konusundaki fikir ve telkinlerini ağırlıklı olarak Hayrî-nâme'sindeki "Matleb-i Hüsn-i Kelâm-1 Mevzûn" başlıklı bahse dayandıracağımız için, ilk olarak bu bölümü okumak yerinde olacaktır:

"1 Ey safâ-yâb-1 kelâm-1 mevzûn Âşinâ-yı sühan-1 gûnâgûn

2 Tab'un eylerse eger şi're heves Sana ma'nâsını fehm itmek bes

3 Sühanân-1 şuarâ-yı eslâf Kalbi âyîneveş ider şeffâf

4 Türkîde Nef'î ile Bâkî'ye bak Gayrı dîvânları da kıl mülhak

5 Anlarun şi'ri metîndir ammâ Gayrisinde dahı var çok ma'nâ 6 Şuarâ-yı Acemün dîvânı Hüsn-i ma'nî ve maârif kânı

7 Tâlib ü Sâ'ib ü Örfî vü Selîm Feyzî-i Hind Nazîrî vü Kelîm

8 Tâze-gûyân-1 zamânda Şevket Ma'nî-i tâzeye virdi sûret

9 Sâhib-i Hamse Nizâmî Husrev Her biri cilvede bir ma' nî-i nev

10 Câmî vü Enverî vü Hâkānî Her biri mülk-i suhan sultânı

11 Bülbül-i şâh-tırâz-1 Şîrâz

Sa'dî vü Hâfız-1 ma'nî-perdâz

12 Suhanân-1 kudemâ-yı şuarâ Hak budur biri birinden a'lâ 
13 Yok nihâyet şuarâ-yı Acem'e Hep esâmîleri sığmaz kaleme

14 Bizde var ekserinün dîvânı

Oku fehm eyle de gör vicdânı

15 Şi' ri çokdur şuarâ-yı Arab'un

Ki odur mâyesi Şâm ü Halebün

16 Dime ebyâtına nâ-mevzûndur Anun evzânları dîger-gûndur

17 Niçe ma'nâları var raks-âver Meş'al-âsâ döker esmâ'a şerer

18 Var içinde niçe eş âr-1 kibâr Ki komaz âyine-i dilde gubâr

19 Niçe bin na't-1 şerîf-i Nebevî Midhat-ı mu'cize-i Mustafavî

20 Her biri kıt'a-i elmâs-1 semîn

Her biri dürr-i girân-kadr-i metîn

21 İntisâba çalış ol eş'âra

Ara ma'nâsını fehme çâre

22 Arabî bilmeyicek iş bitmez

Fârisî ârife tenhâ yitmez

23 Arabî ile olur cümle 'ulûm İlm olur bî-Arabî nâ-mefhûm

24 Lügat ü elsüne sultân Arabî Arabî kıble-i Kur'ân u Nebî

25 Bu iki bâl ile eyler pervâz Tâ'ir-i şi'r-i ma'ânî-perdâz 
26 Hikmet-âmîz gerekdür eş'âr Ki me’âli ola irşâda medâr

27 Âb-1 hikmetle bulur neşv ü nemâ Gülşen-i şi'r ü riyâz-1 inşâ

28 Olmasa şi'r mecâz-1 mutlak Virse ma'nâya hakîkat revnak

29 Yohsa her nazm-1 tehî vü sâde Ola ma'nâdan o da âzâde

30 Tâze mazmûndan ola ol hâlî Olmaya tevriye ile hem mâlî

31 Bâ-husûs olmaya teşbîh tamâm İstiârât ü cinâs ü îhâm

32 Dimeden şi'ri sükût evlâdır Şi'rden maksad olan ma'nâdır

33 Baksan ekser suhan-1 şâir-i hâm Zülf ü sünbül gül ü bülbül mey ü câm

34 Çıkamaz dâ'ire-i dil-berden Kadd ü hadd ü leb ü çeşm ü berden

35 Geh bahâra tolaşur geh çemene İlişür serv ü gül ü yâsemene

36 Reh-i nâ-reftede cevlân idemez Sapa vâdîleri seyrân idemez

37 İdemez sayd-ı maânî-i bülend Atamaz gayr şikârına kemend

38 Geçinür ma'nî-i hâyîde ile Lafz-1 meşhûr u cihân-dîde ile 
39 İki har-vârdur o beyt-i dütâ

K'olmaya tâze kumâş-1 ma'nâ

40 Söyleme şi'ri tehî ma'nâdan

Ağunı çekme balıksız mâdan

41 Nazm kim olmaya ma'nâya karîn

Kendüdür hâtem-i bî-nakş-1 nigîn

42 Şi'r r-i bî-ma'nî-i bî-îhâma

Benzer ol câmeken üzre câme

43 Kokusuz lâleye benzer o sühan

Ki ola lafzı tehî ma'nâdan

44 Benzer ol matla'-1 hâlî hâma

Mağzdan hâlî olan bâdâma

45 Ânı yok dil-bere benzer o kelâm

K'olmaya anda cinâs ü îhâm

46 Öyle pâkîze gerekdür eş'âr

$\mathrm{Ki}$ anı bir işiden ola hezâr

47 Ola ma'nâsı güzel lafzı metîn

Hâme hâke koya dest-i tahsîn

48 Hicvden el-hazer ey cân-1 peder

Ki virir meşreb-i irfâna keder

49 Hüsne sarf eyle sözi şâir isen

Halkı teshîre çalış kâdir isen

50 Tîz ferâmûş olunur nesr suhan

Nazm ammâ ki ider devr-i dehen

51 El-hazer hicvün olur gâyeti şûm

Halk beyninde hakîr ü mezmûm 
52 Hicve mâ'il süfehâdur ancak Âkil itmez anı eyler ahmak

53 Hicvdür kā'ide-i hod-kâmî Hicvdür vâsıta-i bed-nâmî

54 Kisve-i nazmda grybetdür hicv Sebeb-i zenb ü nedâmetdür hicv

55 Hicv kat kat sebeb-i rû-siyehî Kim okursa sana â'id günehi

56 Seni itmiş biri farzâ dil-gîr Kavl ile fi'1 ile kalbün tekdîr

57 Anı lâzım mı hemân hicv itmek Süfehâ gitdigi râha gitmek

58 İnkisârı yetişür kâsır ise İntikâma çalışur kâdir ise

59 Anı sen lutf ile eyle bende Afv ü ikrâm ile it şermende

60 Lafzdur mühr-i dehân-1 esrâr Olamaz lutf-veş efsûn-ken mâr

61 Sana bî-vech ise itdigi cefâ Sebeb-i şerm ü hicâb olur aña

62 Vechi varsa sebebin eyle su'âl Olma âteş-zen-i kânûn-ı cidâl

63 Belki nâdim ola etvârından İtizâr eyleye güftârından

64 Sen kabûl eyle bu pendi benden Dostluk var iken olma düşmen"

(Nâbî 1292/1875: 37-39; Kaplan 1995: 257-62). 
Şimdi bu bölümde ifade edilen belli başlı düşünceleri ele alıp değerlendirmeye başlayabiliriz:

\section{Vezinli sözden zevk almak ve türlü söze aşina olmak}

Nâbî, Hayrî-nâme'sinin bu bahsinde sevgili oğluna "Ey vezinli sözden safâ bulan, zevk alan, çeşit çeşit söze, şiire aşina olan (çocuğum)!" diye hitab ediyor. Böylece şiir sanatının uzun zaman tekrar edilegelen tarifinde yer alan vezin şartına temas ediyor; insan tabiatı üzerinde "vezinli, kafiyeli ve muhayyel" sözün, vezinsiz, kafiyesiz söze, yani nesre nazaran daha tesirli olduğunu da ima ediyor.

Şair, bahsin başında, henüz yedi yaşında olan oğlunu şiire özendirici ve iltifat edici hitabın hemen ardından, "Yaratılışın şiire heves ederse, sana onun manasını anlamak yeter" diyor. Buradan oğlu Ebü'lhayr Mehmed'e şair olmayı tavsiye etmediği, onun sadece şiirin manasını anlamasını yeterli bulduğu neticesi çıkarılabilir... Ancak aynı bölümün sonlarında yer alan şu beytinden, oğlunun eğer gücü yeterse, insanları büyüleyecek derecede güzel şiirler yazmasını istediği de anlaşılmaktadır:

\footnotetext{
"Hüsne sarf eyle sözi şâir isen

Halkı teshîre çalış kādir isen"
}

Nâbî Efendi, geçmiş (büyük) şairlerin sözlerinin kalbi ayna gibi parlattığı kanaatindedir. Böylece önceki sanatkârların eserlerini okumanın, insan kalbindeki kederi, tasayı, dünyevî kaygıları giderdiğini, kişiye zevk ve safâlar verdiğini belirtmiş oluyor.

\section{Hangi Türk şairlerini okumalı?}

Peki, oğlu hangi şairlerin eserlerini okumalıdır? O, "hayır babası" olmasını dilediği Mehmed'e, Türkçe'de Nef'î ve Bâkî'nin eserlerini okumasını, başka divanları da bunlara eklemesini tavsiye ediyor: "Onların şiiri sağlamdır ama başkasında da çok mana vardır." Nâbî Efendi'nin burada mahlaslarını andığı iki Osmanlı şairinden biri olan Bâkî (9331008/1526-1600), bilindiği gibi, 16. asırda "sultânü'ş-şuarâ" (şairler sultanı) sayılan bir edebî şahsiyettir. Aynı asrın ikinci ve 17. asrın ilk yarısında yaşayan Nef'î (980?-1044/1572?-1635) ise, bilhassa medhiye ve 
fahriye türündeki kasideleri, ayrıca hedef aldığı kişileri hırpalayıcı hicviyeleriyle meşhur bir şairdir.

Zaman zaman lirik ve âşıkane şiirler söylemiş olsa da daha ziyade hikemî ve didaktik şiirleriyle tanınan Nâbî Efendi'nin, selefleri arasında dinî, ahlâkî ve tasavvufî eserleriyle meşhur edebî şahsiyetleri değil, bu iki ismi takdirle anarak tavsiye etmesi, doğrusu onun poetikası bakımından şaşırtıcı sayılabilir. Çünkü söz konusu şairlerden Bâkî, şiirlerini okuyanlarca malûm olduğu üzere, umumiyetle cismanî nimetlere alâkasını ve düşkünlüğünü tasvir eden, rind meşrepli bir sanatkârdır. Başka bir ifadeyle, ekseriya sevgilinin güzellik unsurlarından, bahardan, gülden, meyden bahseden, mecazî aşktan dem vuran, "dilber dâiresinden çıkamaz" şairler sınıfına dahil edilebilir. Nâbî́nin burada okunmasını istediğ ${ }^{2}$ Nef' $̂$ ise, biraz önce söylediğimiz gibi, methiye (övgü), fahriye (övünme) ve hicviye (yergi) türündeki manzumeleriyle tanınan;, Hayrînâme sahibinin övünme, yerme, nefret, düşmanlık, incitme gibi kusur sayarak oğlunu sakındırdığı davranışları âdet edinmiş bir sanatkârdır. Bununla birlikte Nâbî̀nin, Bâkî ve Nef' î'ye ait şiirleri tavsiye etmesinin sebebi, herhâlde onları "metîn" (sağlam) bulmasıdır. Şair, "metîn" kelimesiyle anılan iki şairin şiirlerinin söz ve mana bakımından pürüzsüz ve kusursuz göründüğünü, itiraz edilecek bir yönünün bulunmadığını ifade etmiş olmaktadır.

Türkçe yazmış şairler arasında Bâkî ve Nef'î́nin şiirleri okunmalı; ama başka edebî şahsiyetlerin eserleri de bunlara ilâve edilmelidir. Nâbî'nin kendi zamanında veya önceki asırlarda yaşamış nice Türk şairini okuduğunu gösteren çokça delil vardır elimizde: Meselâ, Hayrî-nâme sahibi, Fuzûlî (ö. 963/1556) (Bilkan 1997: I/175-76), Rûhî-i Bağdâdî (ö.1014/1605) (Bilkan 1997: I/172-73), Şeyhülislâm Bahâyî (10101064/1602-1654) (Bilkan 1997: I/174-75), Habeşî-zâde Rahîmî (ö.1140/1727) (Bilkan 1997: I/177-78) gibi şairlerin birer gazelini tahmis etmiştir. Onun başka manzumelerinden de eserlerini okuduğu bazı Türk şairlerininin isimlerini tahmin ve tesbit etmekteyiz: Sanatkârımız, meşhur İranlı mutasavvıf, şair Hakîm Senâyî (464-525? /1072-1131?) hakkındaki bir manzumesinde, 17. asrın tanınmış edebî şahsiyetlerinden Nev' $\hat{1}^{-}$ zâde Atâyî'yi (991-1045/1583-1635?) de takdirle anar. Bu manzumeden öğrendiğimize göre, bir gece Halep valisi Silâhdar İbrâhim Paşa'nın, iki 
fazıl ve bilgili molla, Nâbî, naib ve divan kâtibi gibi kişilerin bulunduğu meclisinde fazilet, ilim ve irfandan bahsedilmiş; söz sözü açmış; o arada Atâyî'nin eseri üzerinde durularak Hamse'sinin lezzeti anılmış. Meğer Paşa'nın kitaplığında bahis konusu eserin bir nüshası varmış. Hemen getirtilip tefe'ül edilerek mesnevinin bir sayfası açılmış; karşılarına mest meczup vak'ası çıkmış (Bilkan 1997: I/434-36).

Nâbî, şiirlerinde atasözlerini ve halk tabirlerini ustaca kullanmasıyla meşhur Bosnalı Sâbit'i (ö. 1124/1712) bu meziyeti yönünden takdir eder:

Darbü'l-mesel îrâdına bu 'asrda Nâbî

Kimse olamaz Sâbit Efendi'ye resîde (Bilkan 1997: II/987)

[Nâbî! Bu asırda atasözü, deyim ve bunlara benzer hikmetli söz söyleme konusunda kimse Sâbit Efendi'ye erişemez.]

Fakat yine onun hakkındaki başka bir beytinde, asıl hünerin âleme mesel (atasözü) gibi kalacak güzel söz söylemek olduğunu da tariz yollu ifade etme gereği duymuştur: “Der-Hakk-1 Sâbit Efendi

Sözde darbü'l-mesel îrâdına söz yok ammâ

Söz odur âleme senden kala bir darb-1 mesel

(Bilkan 1997: II/1255)

[Sâbit Efendi Hakkında- Şiirde atasözü, deyim veya bunlara benzer hikmetli sözler söylenmesine denecek bir şey yok. Fakat söz odur ki, dünyaya senden atasözü gibi kalsın!]

Nâbî Efendi'nin kendi devrindeki bazı şair ve yazarların eserleri için yazdığı takrizler onun, zamanında üstad sayılan, itibarlı bir sanatkâr olduğunu ima ettiği gibi, çağındaki edebî faaliyetleri alâkayla takip ettiğini de düşündürmektedir. Meselâ Nâbî, Na'tî Mustafa Beğ'in (ö. 1130/1718), 1114 (1703) senesinde Cevrî́nin Hilye-i Çihâr-Yâr-i Güzîn'ine bir zeyl $1^{2}$ olarak meydana getirdiği manzum hilye için aynı nazım şekli

${ }^{2}$ Her ne kadar Nâbî Efendi takrizinin başlı̆̆ında Na'tî Beğ'in eserini “...Hilye-i Hâkānî zeyli..." olarak vasıflandırmışsa da söz konusu sanatkâra ait hilyenin, Hilye-i Hâkānî́ye değil, Cevrî İbrâhim Çelebi'nin (1005?-1065/1595?-1654) Hilye-i Çihâr-Yâr-i Güzîn adlı manzumesine zeyl olduğunu belirtmek yerinde olacaktır. 
ve aruz kalıbıyla bir takriz kaleme almış (Bilkan 1997: I/389-90); Manisalı Birrî́nin (1080-1128/1669-1716), 1117 (1705) yılında tamamladığ1 Bülbüliyye isimli mensur eserine takriz yazmış (Birrî Mehmed, Manisa İl Halk Ktp. nr. 5181, vr. 4 a-b; Zavotçu 2007: 80; Erkul 2000: 12); ayrıca bu Mevlevî sanatkârın, kendisini ve eserlerini öven terkîb-bendine (Bilkan 1998: 31-39; Erkul 2000: 201-206) cevaben 1119 (1707) yılında takdir, memnuniyet ve iyi dileklerini ifade eden bir kaside nazmetmiş (Bilkan 1997: I/149-50); aynı duygularını ona mensur bir mektupla da bildirmiştir (Bilkan 1998: 40). Nâbî, Halepli tarihçi Naîmâ'nın (1065?-1128/1655?-1716) eserlerindeki üslûp güzelliğini ise "Âsâr-1 Naîmâ'ya takrîzdür" başlıklı bir rubaîsinde belirtir (Bilkan 1997: II/1173).

Onun kendi çağında yaşayan şair ve yazarların eserlerini okuduğunu gösteren beyanları konusundaki örnekleri artırmak mümkündür elbette. Fakat sözü uzatmamak için, bu hususta bir- iki misâl daha vermekle yetineceğiz: Nâbî, bir kıt'asında kendi devrinin şairlerinden Osmanzâde Tâ'ib'i (ö. 1136/1724) dil kılıcını iyi kullanması ve yeni üslûbu dolayısıyla tebrik ve takdir eder (Bilkan 1997: II/1159). Ciddî ve hikemî şiirleriyle ünlü sanatkârın bazan şakaya şakayla, sataşmaya da ona benzer biçimde karşılık vermek mecburiyetinde kaldığı anlaşılmaktadır. Meselâ, "Hevâî" mahlasıyla mizah ve hicve ait manzumeler yazan Kubûrîzâde Abdurrahman Rahmî (ö.1127/1715), aynı zamanda Nâbî'nin bir kısım gazellerini tehzil etmesiyle tanınmış; eğlenceli söze düşkün, muzip bir şairdi. Nâbî Efendi, kendi ciddî şiirlerini gülünç hâle getirmeyi âdet edinen bu "Hevâî" şairi ve şiirde onunla birleşen Kıyâmî'yi dört mısradan ibaret bir kıt'ayla "fena benzetmiştir"(Bilkan 1997: II/1146).

Buraya kadar saydıklarımız, Nâbî́nin isimlerini açıkça andığı şairlerdir. Divanı, nazireleri tesbit maksadıyla mukayeseli olarak incelenirse

Çünkü Cevrî, dört halifenin fizikî portresi mahiyetindeki eserini Hâkānî Mehmed Beğ'in (ö. 1015/1606) Hilye'sine imrenerek ve bir zeyl olmak üzere yazmış; onun bu manzumesini takdirle anan Na'tî Mustafa Beğ ise, Aşere-i Mübeşşere (Cennetle müjdelenen on sahabe)'den geri kalan altı kişinin hilyesinin kimse tarafindan "nazm ile edâ" edilmediğini düşünerek manzumesini meydana getirmiştir (Daha fazla bilgi için Ceyhan 2006: 1-28). 
tahmin ediyoruz ki onun çok sayıda şiirini başka şairlere ait manzumeleri tanzir yoluyla yazdığı tesbit edilebilecektir. Nitekim biz Nâb̂̂ Dîvânı'nı okurken, bazı manzumelerin önceki asırlarda veya sanatkârın kendi çağında yaşayan şairlerin şiirlerine nazire olduğunu tahmin ettik. Meselâ,

"Görmedüm râh-1 emîn terk-i recâdan gayrı

Bulmadum hisn-ı hasîn şerm ü hayâdan gayrı"

[(İnsanların elindeki şeylerden) ümid etmeyi bırakmaktan başka emin yol görmedim... Hayâ ve utanmadan daha sağlam bir kale bulmadim.]

matla'l1 gazeli (Bilkan 1997: II/1124) Fuzûlî’nin meşhur gazeline (Akyüz v. dğr. 1958: 397) nazire olarak yazılmış gibi görünmektedir. Yine bir gazelini

"Suhan-gû peyrev olsun hazret-i Râmî Efendi'ye

Ki nazm öyle hoş-makāl ü pür-me'âl olsun"

[Söz söyleyen kimse, Hazret-i Râmî Efendi'nin ardından gitsin ki, şiir öyle hoş sözlü ve mana dolu olsun!...]

beytinden anlaşıldığına göre, Râmî Efendi’nin aynı şekildeki manzumesine nazire niyetiyle söylemiştir. ${ }^{3}$

Demek oluyor ki, şiir sever okuyucu, edebiyat tarihinin meşhur birkaç şahsiyetini tanımayı kâfi görmemeli; başka sanatkârların meydana getirdiği eserlerden de mümkün olduğu kadar faydalanmaya çalışmal1dir.

\footnotetext{
3 Nâbî́nin burada kast ettiği "Hazret-i Râmî Efendi"nin, Râmî Mehmed Paşa (10651119/1655-1708) olduğunu, Bursalı Belîğ'in şuara tezkiresinden öğreniyoruz. Beliğ, güldeste mahiyetindeki tezkiresine Râmî Dîvâmı'ndan "Hemân def'-i humâr-1 kîne itsün bî-me'âl olsun" misraıyla başlayan gazelin üç beytini almıştır (Abdulkadiroğlu 1999: 109). Aslında Râmî Efendi'nin söz konusu gazeli, Edirne Mevlevihanesi şeyhi Enis Receb Dede'nin "Tokunsun tek hemân la'l-i nemek-rîzin leb-i câma/ Katarsan bâde-i nâba nemek kat kat helâl olsun" matlalı gazelinden sonra yazılmış yirmiyi aşkın nazireden biridir. Künhî (Abdulkadiroğlu 1999: 366), Saîd, Habeşîzâde Rahîmî, anılan gazele nazire söyleyen şairlerden birkaçıdır (İnce 2005: 337-38, 402, 555; Genç 2000: 26).
} 


\title{
Fars şairleri
}

Nâbî, Hayriyye'nin bu bölümünde Türk şairleri üzerinde fazla durmadan Fars şairlerinden bahsetmeye başliyor: Ona göre, Acem şairlerinin divanları mana güzelliği ve maarif (ilim, irfan ve hüner) kaynağıdır. Örfî (963-999/1556-1591), Feyzî-i Hindî (954-1004/1547-1596), Nazîrî (ö. 1021/1612), Tâlib", Selîm (ö. 1057/1647), Kelîm (ö. 1061/1651), Sâ'ib (ö. 1087?/1676?), zamanın yeni (manalar, nükteler bulup) söyleyenleri arasinda Şevket-i Buhârî (ö. 1107/1695), Nâbî'nin beğenerek andı̆̆1 Fars şairlerinden bazılarıdır. Hamse sahibi Genceli Nizâmî (535?-611?/1141?1214?) ve Hüsrev-i Dihlevî (651-725/1253-1325) de onun takdirle zikrettiği isimlerdendir. Câmî (817-898/1414-1492), Enverî (ö. 585?/1189?), Hâkānî (520-595/1126-1199), her biri söz ülkesinin sultanıdır. Şiraz'in süsü olan Sa'dî (ö. 691/1292) ve Hâfız (ö. 792?/1390?). Eski şairlerin sözleri doğrusu birbirinden güzeldir. Velhasıl Acem şairlerine son yoktur; onların hepsinin isimlerini burada anmak mümkün değildir. Gerçekten Nâbî, Farsça yazan şairler arasında sevdiklerinin tamamını burada tek tek sayamamıştır. Meselâ, Hayriyyénin başka bir bölümünde mutasavvıf şair ve yazarların eserlerini okumayı tavsiye ederken, Mevlânâ'nın Mesnevîsini bilhassa zikreder:

\author{
“Cümle-i nüsha-i merdân-1 Hudâ \\ Virür âyîne-i idrâke cilâ \\ Himmet it anlamaga güftârın \\ Hırz-1 cân eyleyegör esrârın \\ Tâlib-i Hakk'a olur râh-nümâ \\ Nüsha-i Mesnevi-i Mevlânâ"(Kaplan 1995: 206).
}

[Allah erlerinin kitaplarının hepsi, anlayış aynasını parlatır... Onların sözlerini anlamaya gayret et; sırlarını can muskası gibi korumaya bak!.. Mevlânâ Mesnevîsinin nüshası, Hakk'1 (Allah'1, gerçeği, doğruyu bilmek) isteyene yol gösterici olur.]

\footnotetext{
${ }^{4}$ İran şairleri arasında "Tâlib" mahlasını birden çok şair kullanmıştır. Bunlardan biri, divanı ve Gûy u Çevgân manzumesi olan Tâlib-i Cacarmî olup 854 (1450) yılında vefat etmiştir. Diğgeri ise yine divanı bulunan ve 1035 (1625) yılında Keşmir'de vefat eden Tâlib-i Âmülî̀dir.
} 
Nâbî, Mevlânâ'nın Konya'da bulunan âsitânesini (büyük tekkesini) ziyareti dolayısıyla nazmettiği kasidesinde (Bilkan 1997: I/36-38) ve kabrinin 1110 (1698-99) yılında tamir edilmesi münasebetiyle meydana getirdiği tarih kıt'asında da Celâleddîn-i Rûmî'yi ve onun Mesnevî, Fîh-i mâ-fîh gibi eserlerini över (Bilkan 1997: I/239-41).

Burada andığı şairlerin çoğunun divanı kendi kitaplığında vardır. Oğlu, onları okuyup anlayarak vicdanı görmelidir. Fars şairlerine ait eserlerin okunmasını hararetle tavsiye eden Nâbî, onların sözlerini Türkçe'ye tercüme işini, elbiseyi bozup başka bir giyecek yapmaya benzetir:

"Câme-i gayrı bozup 'anteri yapmak gibidür Nazm-1 Türkîye çevirmek "Acemün güftârın"

(Bilkan 1997: II/875).

[Fars şairlerinin şiirlerini Türkçe'ye çevirmek, başkasının elbisesini bozup entari yapmak gibidir.]

Nâbî, burada tahminimize göre, şiirin tercümesinin aslına ait incelik ve meziyetleri eksiksiz aksettiremeyeceğini belirtmekte veya Farsça yazan şairlerin bulduğu manaları, nükte ve hayâlleri (ç)alıp kendi gücünün mahsulüymüş gibi göstermeyi iğneleyici bir dille tenkit etmektedir.

\section{Arap şiiri}

Nâbî Efendi, Türk ve Fars şairleri hakkındaki umumî fikirlerini, gördüğümüz gibi ifade ettikten sonra, Arap şairlerinden söz açıyor: Ona göre, Arap şairlerinin de şiiri çoktur. Bunlar Şam ve Haleb'in özü, başka bir ifadeyle edebiyat piyasasının sermayesidir. Yalnız "Arap şairlerin beyitlerini vezinsiz sanma. Onun vezinleri başka türlüdür" diyerek Türk, Fars ve Arap aruzu arasındaki farklara işaret etmiş oluyor.

Nâbî'ye göre, Arap şairlerin eserlerinde âdeta kulaklara kıvılcım döken ve insanı heyecandan raksa getiren nice manalar vardır! ${ }^{5}$ Bunların

\footnotetext{
${ }^{5}$ Şiir, işte böyle işitenin içine ister istemez işlemeli; işiten taş kalpli bile olsa ona tesir etmelidir:

"İtse te'sîr dil-i sâmi'a hâh ü nâ-hâh

Dil-nişîn sîne-nişîn sadr-nişîn olsa gazel (...)

Gûş iden seng-dil olursa bile itse eser

Mấil-i mertebe-i nakş-1 nigîn olsa gazel"(Bilkan 1997: II/828-29)
} 
içinde büyüklerin öyle şiirleri vardır ki, gönül aynasında toz, keder b1rakmaz. Hz. Muhammed'i ve onun mucizelerini övmek maksadıyla yazılan binlerce naat bulunmaktadır elimizde. $\mathrm{O}$ eserlerin her biri değerli bir elmas parçası, sağlam ve pahada ağır bir inci gibidir. İşte o şiirlerle alâkadar olmak ve onların manasını anlamaya çare aramak gerekir.

Görülüyor ki, Nâbî Efendi, Arap şairlerinin eserlerinden bahsederken, onların naat türündeki şiirlerini bir nümune olarak kayda değer buluyor. Bilindiği gibi, Arapça naatların en tanınmış olanlarından biri, Ka'b bin Züheyr'in Kasîdetü'l-bürde'si, diğeri ise Bûsirî́nin -zaman zaman mezkûr isimle de anılan- Kasîdetü'l-bür'e'sidir. Elbette o dilde bunlardan başka okunması icab eden daha nice güzel eser vardır (Arap edebiyatında methiye ve na't için bk. Durmuş 2004: XXIX/406-408; Durmuş 2005: XXX/40-456).

\section{Arapça ve Farsça}

Nâbî Efendi'nin bundan sonra bilgili bir insan için Arap ve Fars dillerinin niçin ve ne kadar gerekli olduğu konusundaki düşüncelerini anlatmaya başladığını görüyoruz: Ona göre, evet, Farsça öğrenmek ve Fars şairlerinin eserlerini okumak, anlamak gerekir. Fakat ilim, irfan sahibi bir kişiye Farsça bilmek yetmez sadece! Bundan başka Arapça'yı da iyice öğrenmek lâzımdır. Arapça bilmeyince iş tamamlanmış olmaz. Peki, Arapça'yı öğrenmek neden lüzumludur? Çünkü bütün ilimler, Arapça ile tahsil edilebilir; Arapçasız ilimler anlaşılmamış olur. Şairin kanaatince, Arapça bütün söz(lük) ve dillerin sultanıdır. Zira Arapça, Kur'ân'1 ve Hz. Muhammed'in hadislerini anlamak için yönelmek gereken lisandır. Manalar düzenleyen şiir kuşu, bu iki kanatla, yani Arapça ve Farsça'yla uçar.

Bilindiği gibi, İslâm kültür ve literatüründe hem aklî́- zahirî ve dinî ilimleri, hem de tasavvufî- bâtınî ilimleri elde etmiş olan kişilere "iki kanatlı" manasında "zü'l-cenaheyn" denir. Burada şairin ilim çeşitlerinin değerini ve gerekliliğini belirtmek üzere kendisinin de kullandığı bir 
benzetmeyi ${ }^{6}$, hem Arapça, hem de Farsça'yı öğrenmenin ne kadar lüzumlu olduğunu ifade etmek için, tekrar andığını görüyoruz: Ona göre, Arapça ve Farsça, bir kuşun iki kanadı gibidir. Nasıl tek kanatlı kuş uçamazsa, sadece Farsça öğrenmek de istenen hedefe ulaşmaya yetmeyecektir.

Şair, Hayrî-nâme'nin ilimlerin çeşitlerini bilme bahsinde de sarf, nahiv ve Arapça ile alâkalı diğer şeylerin gerekli olduğunu ifade eder. Fakat bütün vakitleri alet ilimleriyle geçirmemek lâzım geldiğini, amel etmeksizin (veya pratik yapmaksızın) aletlerin işe yaramayacă̆ını da belirtme lüzumu duyar:

Sarf ü nahv ü Arabiyyet lâzım

Arabî bilmege âlet lâzım

Lîk âletle geçürme evkāt

Bî-taammül neye yarar âlât (Nâbî 1292/1875: 13)

Bilindiği gibi, İslâm âlimleri tarafından yapılan ilim tasniflerinden biri de "âlî ilimler" ve " 'âlî ilimler" şeklindedir. "Âlî ilimler"den maksat, sarf, nahiv, cedel, mantık gibi kendileri için öğrenilmeyen, ancak yüksek dinî ilimlere vasıta olan veya sayılan bilgilerdir. " 'Âlî ilimler"

${ }^{6}$ Nâbî, Hayrî-nâme'nin "Matleb-i Dâniş-i Envâ'-1 Ulûm” başlıklı bölümünde, zahirî ilimlerin kuşun bir kanadı, bâtınî ilimlerinse başka bir kanadı mesabesinde olduğuna şöyle işaret eder:

"Kalma kışrında 'ulûmun ammâ

Olagör vâsıl-1 lübb-i ma'nâ

Zâhirün bâtınına eyle 'ubûr

Yeke perle uçabilsün mi tuyûr" (Kaplan 1995: 202).

[Ama ilimlerin kabuğunda kalma; mananın özüne erişmeye bak! Zahirin, görünenin iç yüzüne geç... Kuşlar tek kanatla uçabilir mi?] Şair, Hayrî-nâme'nin başka bir bahsinde "zâhir"den maksadın İslâm dininin dış hükümleri, "bâtın"ınsa hakikatın sırları olduğunu, söz konusu iki ilim çeşidini de elde etmeye çalışmak gerektiğini ifade eder:

"Zâhir ahkâm-1 şerî́atdür hep

Bâtın esrâr-1 hakîkatdür hep

Vaktüni sarf idegör tahsîle

İkisin dahı çalış tekmîle"(Kaplan 1995: 207). 
terkibiyle ise hadis, tefsir, fıkıh, tasavvuf gibi yüksek dinî ilimler kast edilir. Nâbî Efendi, alet ilimlerinin gerekli olduğunu, fakat değerli zaman sermayesinin büyük bir kısmını veya tamamını bunları tahsil etmek uğruna harcamamak lâzım geldiğini belirtmektedir. Aynı fikri, yirminci asır başlarında Mehmed Âkif de ifade etmiş; medreselerde Arapça öğretiminin çok uzun sürdüğünü, buna rağmen o dili öğrenmeye çalışanların meramlarını anlatmaya muvaffak olamadıklarını ve sadede gelmekte pek geç kaldıklarını teessüfle belirtmiştir (Mehmed Âkif 1326/1910: 304305). Nâbî Efendi, Arapça, sarf, nahiv gibi İslâmî ilimleri tahsile vasıta kabul edilen bilgilerin gerekliliği üzerinde durduktan sonra, fıkıh, hadis, tefsir, tasavvuf gibi İslâmî ilimleri, lüzumu kadar öğrenmeyi tavsiye eder:

İlmün it cümlesini istihsâl

Cümlesin itme velî isti' mâl

Sana kâfîdür ola nakş-1 zamîr

'İlmden fikh u hadîs ü tefsîr

Gayrısın okı velî itme 'amel

Olma pâ-mâl-i da'âvî vü cedel

Fikhdan eyle 'ibâdâta nazar

Eyleme semt-i da'âvîye güzer (Kaplan 1995: 203)

[İlmin hepsini tahsil et; fakat hepsini kullanma. Sana ilimlerden f1$\mathrm{k} ı$, hadis ve tefsir, içinin ziyneti olsa yeter. Başkasını oku; ama onunla amel etme. İddiaların ve tartışmanın çiğnenmişi olma. Fikıhtan ibadetlere bak, itibar et; meseleler tarafına geçme. Satış ve alış meselesini bilmemek sana iki âlemde bir eksiklik vermez.]

Hikmet ü felsefeden eyle hazer

Evliyâ nüshasına eyle nazar (...)

Mürşid-i kâmil olınca nâ-yâb

Sana mürşid yitişür şimdi kitâb (Kaplan 1995: 204)

[Hikmet ve felsefeden sakın; velilerin kitabına bak! (...) Kâmil mürşid bulunmayınca, sana şimdi doğru yol gösterici olarak kitap yeter.]

Görüldüğü gibi, Nâbî Efendi, kültürlü bir insanın Fars şair ve yazarlarının eserlerinden istifade edebilmek için Farsça; İslâmî ilimleri ve Arap şairlerinin şiirlerini okuyup anlayabilmek için de Arapça öğren- 
mesi lâzım geldiği kanaatindedir. İstanbul'un şerefini anlatırken, taşra yerlerde ilim ve irfandan eser kalmadığını, oralardaki halkın şiir ve sanatlı nesirden nefret ettiğini üzüntüyle ifade eden şair, kenarda konuşulan Arapça'nın doğru, düzgün ve dil bilgisi kaidelerine uygun olmadığından bahsederken, kar gibi soğuk göründügünü de ifade eder (Kaplan 1995: 211). Burada yeri gelmişken şunu da belirtmek gerekir ki, Nâbî, şiir ve nesirde garip, yani okuyucuların çoğu tarafından bilinmeyen, alışılmadık yabancı kelimelerin kullanılmasını doğru bulmayıp tenkid eder:

Ey şi'r miyânında satan lafz-1 garîbi

Dîvân-1 gazel nüsha-i kāmûs degüldür (Bilkan 1997: I/587)

[Ey şiir arasında garip kelimeleri (kullanarak bilgiçlik) satan! Gazel kitabı, lûgat nüshası değildir!]

Şaire göre, öyle çözülmesi danışmaya muhtaç, düğümlü, manası az, sözü işitilmemiş, her satırı lûgata bakmaya sebep olan şeylere şiir ve inşa (sanatlı nesir) denmesi uygun değildir:

Dinsün mi şi'r ü inşâ öyle mu'akkadâta

Kim ola hall ü 'akdi muhtâc-1 istişâre

Endek ola me'âli nâ-gûş-zed makāli

Her satr ola müeddî kāmûsı ihtizâra (Bilkan 1997: II/1060)

[Öyle çözülüp açıklanması danışmaya muhtaç, düğümlü, manası az, sözü duyulmamış, her satırı lügatı hazır etmeye sebep olan şeylere 'şiir' ve 'inşa' (sanatlı nesir) densin mi?!].

Şair, başka bir beytinde, açı açık söyleme yerinin caddesi dururken, manayı, ihtimâlin kapalı sokağına esir etmenin uygun olmayacağını ifade eder:

Tururken şâh-râh-1 'arsa-i tasrîh ma'nây1

Degül lâyık esîr-i kûçe-bend-i ihtimâl itmek (Bilkan 1997: II/815)

Görüldüğü gibi, burada belâgatta kusur sayılan şeylerden ikisine, "ta'kîd" ve "garâbet"e temas edilmekte; okuyucu, danışmaya muhtac olacak denli anlaşılması güç sözleri şiir diye meydana getirmekten, ayrıca nazım veya nesirde alışılmadık kelimeler kullanmaktan sakındırılmaktadır. 


\section{Türkçe sevgisi}

Nâbî'nin Arapça ve Farsça öğrenmenin lüzumunu anlatırken Türkçe'den bahsetmeyişi, oğluna bu dili iyice öğrenmeyi telkin etmeyişi, tenkit ve itiraz konusu olabilir belki. Ancak şunu hatırla(t)mak gerekir ki, şair, Hayrî-nâmesini ve Farsça Dîvançesi dışındaki bütün diğer eserlerini Türkçe yazdığına göre, oğlu zaten Türkçe bilmektedir. Bu arada Nâbî'nin Halep'te yaşarken İstanbul Türkçesi'nin güzelliğine, İstanbul erkek ve hanımlarının nazik ve nükteli konuşma tarzına duyduğu hasreti, çeşitli vesilelerle dile getirdiğini de belirtmek yerinde olur. Meselâ,

Şehr-i Sitânbulun ne güzel merdümânı kim

En sâde-levhi nâzik olur nükte-dân olur (Bilkan 1997: I/515) güzeldir!]

[İstanbul'un en saf kalplisi bile nazik ve nüktedan olan insanları ne

Dilber-i harf-nedân-1 ‘Arabistân göreli

Çeşm-i şevkümde uçar Rûm ilinün hûbları (Bilkan 1997: II/1079)

[Arabistan'in söz söylemeyi bilmeyen dilberini göreli, Anadolu'nun güzelleri şiddetli isteğimin gözünde tütüyor.]

Naz ve işve biçimlerini bilenlerin İstanbul güzelleri olduğunu belirten şu beytin ikinci mısra1, hem Nâbî Efendi'nin, hem de bütün divan şiirinin berceste mısralarından biridir:

Bilen hâk-i Sitanbul'dur rüsûm-1 şîve-i nâzı

Kenârun dilberi nâzik de olsa nâzenîn olmaz

(Bilkan 1997: II/685)

[Naz ve işve şekillerini bilen, İstanbul toprağı İ̀stanbullu güzellerdir. Taşranın dilberi nazik de olsa ince, nazlı ve hoş edalı olmaz!]

Şair, ayrıca uzun zamandır taşrada yaşamak dolayısıyla dilinin inceliğini kaybetmeye yüz tutmasından şikâyetçidir:

Nâbî 'aceb mi sözlerümüz olsa bî-nemek

İstânbul'un lisânın unutduk kenârda (Bilkan 1997: II/981)

[Nâbî! Sözlerimiz tatsız, tuzsuz olsa, şaşlır mı buna? İstanbul dilini unuttuk taşrada.] 
1122 (1710) yılında Baltacı Mehmed Paşa ikinci defa sadrazam olarak Halep'ten İstanbul'a gelince, sohbetinden hoşlandığı şair Nâbî́yi de birlikte getirmiştir. Yaşlı şair, Sultan III. Ahmed'e teşekkür maksadıyla sunduğu uzunca bir kasidede İstanbul Türkçesinin, Halep'te konuşulan mahallî Arapça'dan daha güzel, ince ve tatlı olduğunu da mukayeseli bir şekilde anlatır. Ona göre, kulağın gidası, temiz sözlü mana; gözün gıdası ise güzelliktir. İnsanın kulağı taşralarda İstanbulluların tatlı sözlerini duymayı özler; gözü de bu şehirlilerin endamının o nazik kıyafetini görmeyi ister. Bütün üslûp, şive ve eda güzelliği, o eşsiz şehirde, İstanbul'da son derecesini bulur. O gönül açıcı sözler, o ince nüktelerle gözü aydınlatan güzellerin Arabistan'da duyulması, görülmesi mümkün değildir. Kendisinin ihtiyarlık çağında beden rahatını terk ederek İstanbul'a gelmesinin sebeplerinden biri işte budur. (Bilkan 1997: I/119-20; Bilkan 1998: 97-108).

Nâbî'nin dillerle alâkalı bu beyanlarından da anlaşılacağı üzere, Arapça, Farsça ve Türkçe İslâm medeniyetinin üç büyük dilidir. Müslüman bir şair- yazar tarafından Arapça ve Farsça, yabancı diller olarak görülmemekte; bilakis ilim ve irfan tahsil etmek, edebî bilgiler edinmek isteyen bir kişinin öğrenmesi gerekli iki lisan sayılmaktadır. Şairin Arapça'ya dinî sebeplerden dolayı daha çok ehemmiyet verdiğini söylemek mümkündür. Nâbî gibi her hangi bir tarihî şahsiyetin Arapça ve Farsça hakkındaki bu fikir ve kabulleri göz önünde bulundurulursa, onun niçin Arapça veya Farsça yazmakta yahut eserlerinde anılan dillerden geçmiş kelimeleri kullanmakta bir mahzur görmediği daha iyi anlaşılabilir. İşte bundan dolayı divan meydanında Arap, Anadolu (Türk) ve Acem dillerine ait sözlerin toplanmasına şaşmamak gerekir:

Ta'bîr-i zebân-1 'Arab u Rûm u 'Acem

Cem' olsa 'aceb mi sahn-1 dîvândur bu (Bilkan 1997: I/450)

\section{Şiir hikmetli olmalıdır}

Nâbî Efendi, şiirlerin manasının irşada, doğru yolu göstermeye vesile olması için, hikmetli olması gerektiği kanaatindedir. Ona göre, su canlıları nasıl geliştirip büyütüyorsa, hikmet de şiir ve nesri aynen öyle yetiştirip büyütecektir. Başka bir ifadeyle, hikmetsiz şiir ve nesir, susuz 
kalmış bir bahçe gibi, canlılığını ve güzelliğini kaybederek solacak ve tarümar olacaktır. Bilge sanatkâr bu fikrini, "Şiir gül bahçeleri ve süslü nesir bahçeleri, hikmet suyuyla gelişir; serpilir." manasındaki beytiyle ifade eder. Şair bir gazelinin sonunda, belirli bir çağdan sonra içki ve sevgiliyi anlatmanın, övmenin kendisine yakışmayacağını söyleyerek "Nâbî! kaleminin ağzını hikmete alıştır." der:

Şimden girü düşmez sana vasf-1 mey ü mahbûb

Nâbî dehen-i hâmeni kıl hikmete mu'tâd (Bilkan 1997: I/494).

Bu söz, insanın yaşama kuvvetinin, tabiî hararetinin azalmaya başladığ 1 belirli bir yaştan ve nice hayat tecrübesi kazandıktan sonra, artık içki, aşk, meşk sözlerini bir tarafa bırakıp aklını başına toplaması, olgunlaşması ve bilgece yazılar yazması, eserler meydana getirmesi gerektiğini anlatıyor bize.

Şairimizin yine bu konuyla alâkalı bir temennisi de şiirde yalnız mecazın işlenmemesi, hakikatin manaya canlılık ve tazelik vermesidir. Onun burada "mecaz" kelimesiyle gerçek dişı şeyleri ve "mecazî aşk" da denen beşerî aşkı kast ettiğini tahmin ediyoruz. Nitekim Nâbî, bir gazelinin başında "Ayrılık derdinden şikâyet edenlerin ve mecazî güzellik arzusuyla feryad ü figan edenlerin güzelliği yok." diyor:

Yok hüsni şekve-i gam-1 hicrân idenlerün

Hüsn-i mecâz şevkine efgān idenlerün (Bilkan 1997: II/784).

Aşkın, edebiyat ve müzik eserlerinde en çok işlenen, dile getirilen, anlata anlata bitirilemeyen konulardan biri olduğu, malûmdur. Bu fiilî duruma ahlâkî ve kültürel sebeplerden ötürü itiraz eden Nâbî Efendi'ye göre şiirde, sözde hep beşerî aşk konuları ve duyguları anlatılmamalı; hakikat, manaya güzellik ve canlılık vermelidir. Beşerî aşkı anlatan şiir, hikâye ve şarkıların cemiyette belirli bir yaş grubuna mensup fertlere, yani gençlere hitap edebileceği, zevk ve heyecan verebileceği, nüfusun büyük bir kısmını teşkil eden çocuklar, hastalar, yaşlılar ve felâketzedeler içinse pek bir şey ifade etmeyeceği de söylenebilir bu arada. Kısacası, sanatkâr, eserlerinde devamlı dar bir daire içinde dönüp durmamalı; insanın muhtac olduğu hakikatlerden, hikmetten, faziletten de bahisler açmalı; ona doğru yolu göstermelidir. 
Dindar bir şair ve yazar olan Nâbî Efendi'nin "Şiirlerin hikmetli olması gerekir ki, manası irşada vesile olsun" görüşünün hikmet, nasihat, iyiliği tebliğ ve kötülükten sakındırmayla alâkalı İslâmî kaynaklara, Kur'an âyetlerine ve Hz. Muhammed'in hadislerine dayandığını tahmin etmek zor değildir. "Hikmet" kelimesi, "Kime hikmet verilirse, ona pek çok hayır verilmiş demektir" (Kur'an: Bakara, 2/269) mealindeki ayette olduğu gibi, Kur'ân'ın pek çok ayetinde geçer. Allah'ın güzel isimlerinden birinin de "Hakîm" olduğu malûmdur. Hz. Muhammed'in, "Beyanın bazısı büyü gibidir; şiirin bir kısmı da hikmettir" (Buhârî: "Edeb", 90; Tirmizî: "Edeb", 69) mealindeki hadisinde şiirin hikmetli olanını övdüğü bilinmektedir. Yine Hz. Muhammed'in Tarafe, Kus bin Sâide, Ümeyye bin Ebî Salt, Ka'b bin Zuheyr, Lebîd bin Rebîa, Abdullah bin Ravâha, Hassan bin Sâbit gibi gerek Cahiliye devrinde yaşamış, gerekse hem Cahiliye, hem de İslâm devrini idrak etmiş olan bazı Arap şair veya hatiplerinin şiirlerini, hitabelerini zaman zaman söylediği yahut beğenerek dinlediği sabittir. Meselâ, Hz. Peygamber, bir haber gecikecek olsa, Muallâka şairlerinden Tarafe'nin (ö. 564?) "Günler yakında sana bilmediklerini gösterir ve kendisine yol azığ vermiş olmadığın kimse sana haberler getirir..." manasındaki misralarını okurdu (Ahmed bin Hanbel, Müsned: 6, 31, 138; Tirmizî, "Edeb", 70). Ayrıca, bir hutbe esnasında "Şairlerin söyledikleri içinde en doğrusu, Lebîd'in şu sözüdür." diye Lebîd'in (ö. 40 veya 41/660 veya 661) "Haberiniz olsun, Allah'tan başka her şey bâtıldır; her nimet de şüphesiz zevâle mahkûmdur" manasındaki beytini okumuştu. (Buhârî: "Edeb", 90; "Menâkıbu'l-ensâr": 20; Tirmizî : "Edeb", 70).

İşte Nâbî, bu gibi dinî sebeplerden ötürü, şiirin yazılmaya, söylenmeye, dinlenmeye lâyık olması için, içinde hikmet bulunması gerektiği kanaatindedir. Kendisinin şiir sanatına bu kadar yönelmesini ve alâka göstermesini de hikmetleri anlatma maksadına bağlar:

Teveccüh itmez idüm şi're Nâbiyâ bu kadar Beyân-1 sırr-1 hikem olmayaydı mazmûnı (Bilkan 1997: II/1104)

[Ey Nâbî! Eğer manası hikmetler sırrını anlatmak olmasaydı, şiire bu kadar yönelmez, ilgi göstermezdim.] 
Sanatkârın şu beyti onun şiiri, cami, köprü gibi kalıcı ve faydalanıldığı müddetçe sahibinin amel defterinin açık kalmasını sağlayıcı bir hayır vasıtası olarak gördüğünü düşündürmektedir:

Kiminün câmi'i var kimi yapar pül Nâbî

Şu'arânun n'olur âsârı suhandan gayrı (Bilkan 1997: II/1095)

[İnsanlardan kiminin camii var, kimi de köprü yapar. Nâbî! Şairlerin eserleri sözden başka ne olabilir ki?]

Yine o, yeni bir mana taşımayan şiirler yazmayı faydasız ve boş şeylerle uğraşmak olarak kabul etmekte; "Eğer mâlâyani (manasız, faydasız, boş) şeyleri terk etmek, İslâm güzelliğinin süsü olmasaydı, yeni manadan hâlî (boş) şiir söyleyici olurdum" demektedir:

Tâze ma'nâdan tehî şi're olurdum leb-güşâ

Terk-i mâ-lâ-ya'ni zîb-i hüsn-i İslâm olmasa

(Bilkan 1997: II/1018)

Aslında şairin mensup olduğu manevî kültürde insana sinırlı bir hareket sahası belirlenmekte; onun hem kendisi ve hem de başkalarının sağlığı, güvenliği, rahatı, huzuru ve esenliği için, bu daire içinde, hududu aşmadan yaşaması istenmektedir. $\mathrm{Bu}$ arada mükellefiyet şartlarını taşıyan kişinin dedikodu, yalan, alay, iftira, lakap takma, sövüp sayma, kötülüğe özendirme, manasız, faydasız şeylerle uğraşma gibi söz veya yazıyla işleyebileceği fiiller de -işaret ettiğimiz gayelere hizmet etmek üzere- hoş görülmeyip yasaklanmaktadır. Nitekim dille işlenebilecek günahlardan kaçınmaya çalışan ve oğlunu da sakındırmaya gayret eden şairin, Hadîs-i Erbaîn Tercümesi'nde, "Müslüman elinden ve dilinden Müslümanların esenlikte olduğu kimsedir."; "Yüce Allah'ı zikirden başka dünya ve onun içindekiler lânetlenmiştir."; Kişinin boş şeyleri terk etmesi, Müslümanlığının güzelliğindendir"; "Belâ, dil yüzünden gelir." gibi hadisleri tercüme ettiğini hatırla(t)mak gerekir (Sevgi 2000: 32, 47, 110, 134). 


\section{Mana, Taze Mazmun ve Edebî Sanatlar}

Nâbî, boş, sade, manasız, içinde yeni bir nükte bulunmayan, tevriye, teşbih, istiare, cinas, îhâm gibi edebî sanatların kullanılmadığı manzumeleri söylemekten, susmanın daha iyi olduğu kanaatindedir. Şaire göre, bir dilber için cazibe neyse, şiir için edebî sanatlar da odur: "Yoksa boş, süssüz, sanatsız, manasız, yeni bir imaj, bir hayal ihtiva etmeyen, tevriye, teşbih, istiare, cinas, îham gibi edebî sanatların kullanılmadığ len şey, manadır."

"Söylenmemiş, yeni manalar meydana çıkmayınca kalemin yüzünün suyunu dökmeğe kıyamam." (Bilkan 1997: II/763) diyen Nâbî́ye göre söylenmemiş sözle tanınmış olanın farkını anlamayan kimse, (güzel şiirin) zevkini idrak edemez (Bilkan 1997: II/772).

Şair, "olsa gazel” redifli gazelinde her yönden güzel ve mükemmel bir gazelin nasıl olması lâzım geldiğini anlatır. Söz konusu manzumenin ilk beytinde

Zâhir ü bâtını ma'mûr ü metîn olsa gazel

Sûrete yâver ü ma'nâya mu'în olsa gazel (Bilkan 1997: II/828)

[Gazelin zâhiri (görünen yüzü, dış tarafı) ve bâtını (içi, manası) bayındır ve sağlam olsa, şekli manaya yardımcı olsa.] diyerek şiirin hem şekil, hem de mana bakımından mükemmel ve sağlam olması gerektiğini ifade eder. Nâbî́ye göre, şiir sanatında başarılı olmanın kıstaslarından biri de onun okuyup dinleyenlerce beğenilmesi, insanlar, hatta melekler tarafından ezberlenmesidir:

Suhan ol denlü hoş-âyende gerekdür ki anı

İdine nev'-i beşer belki melâ'ik ezber (Bilkan 1997: I/62)

[Söylenen sözün (şiirin), o kadar hoşa gidici olması gerekir ki, onu insanlar, hattâ melekler ezberlemelidir.]

\section{Ham Şairleri Tenkit ve Geleneğe İtiraz}

Hayriyye sahibi, şiirlerinde umumiyetle sevgilinin güzellik unsurları, tabiat varlıkları ve içkiden bahseden ham şairleri de tenkid eder; onların gidilmemiş yolda, kestirme olmayan sahalarda dolaşamadığını ve yüksek manaları avlayamadığını, herkesçe bilinen, bayat sözlerle 
geçindiğini belirtir. Böylece yeni konuların ele alınması ve yeni söyleyiş biçimlerinin araştırılıp bulunması gerektiğini ima eder:

"Ham şairlerin sözlerinin çoğu zülf, sümbül, gül, bülbül, içki ve kadehtir. Bunlar, dilber dairesinden (gönlü alıp götüren güzelin cazibe sahasından), boydan, yanaktan, dudaktan, gözden çıkamaz... Bazan bahara, bazan çimene dolaşır; servi, gül ve yasemine takılır... Gidilmemiş yolda dolaşamaz; sapa vadilerde gezemez. Yüksek manaları avlayamaz; gayp avına kement atamaz... Ağızdan ağıza dolaşan, bayat mana, meşhur ve herkesçe bilinen sözlerle geçinir. Hâlbuki içinde yeni mana kumaşı olmayan iki katlı beyit, iki eşek gibidir."

Denebilir ki, bu sözler, edebiyat tarihimizde cismaniyetin dar dairesinden çıkamamış; ilim, irfan ve faziletle olgunluğa erişememiş; duyguları henüz nefs-i emmare hizasında olan şairler eliyle asırlardır devam eden şiir geleneğine karşı ciddî bir itirazdır. Nâbî Efendi, "usandık" redifli gazelinin sonunda da Leylâ ile Mecnun efsanesinden bıktığını belirterek yeni konuların ele alınması ve bilinmeyen maceraların hikâye edilmesi gerektiğini ima eder. (Bilkan 1997: II/756). ${ }^{7}$

Bilge şair, bu fikrinde yalnız ve tek başına kalmış değildir. Onun söz konusu ettiği âşıkane ve rindâne şiirlere yahut efsanevî hikâyelere karşı zaman zaman başka şairler tarafından da tenkitler yöneltildiğini bilmekteyiz. Meselâ, Bosnalı Sâbit Leylâ vü Mecnun, Husrev ü Şîrîn, Vâmık u Azrâ misali defalarca nazma çekilmiş aşk hikâyelerinin artık bir tarafa bırakılıp yeni konuların ele alınması lâzım geldiğini ifade eder (Karacan 1991: 61-62).

Nâbî̀ye göre, şiiri manadan hâlî (boş) söylememek gerekir. Manasız şiir söylemek, ağını sudan balıksız çekmeye benzer. Yine manalı olmayan nazm, yüzüğ̈un nakışsız mührü gibidir. Mana yönünden boş olan söz, kokusuz lâleye benzer. Başka bir örnekle söylemek gerekirse, içi boş olan matla', özü olmayan bir badem misalidir. Cinas ve ihamin bulunmadığı söz, cazibesi olmayan dilbere benzer.

7 Şair, başka bir gazelinde “Olmaz eş'ârında lezzet dil-rübâsız 'âşıkun/ Tûtiyân âyîne-i ruhsâre söyler söylese" (Bilkan 1997: II/971). [Dilbersiz âşı̆̆ın şiirlerinde lezzet olmaz. Papağanlar, çehre aynasına karşı konuşur, konuşursa.] diyerek sevgilisiz âşı̆̆ın söylediği şiirlerde bir tat bulunmayacağını belirtir. 
Şiir, öyle temiz ve halis olmalıdır ki, onu bir işiten, bin olmalı veya bülbül gibi şakımalı. Manzumenin manası güzel, sözü de sağlam olmalıdır. Onu okuyan veya dinleyen, 'Işste şiir böyle yazılır!' dercesine kalemini yere bırakıp hayran kalmalıdır.

\section{"Hicivden sakın!"}

Şair, oğlu Ebü'l-hayr Mehmed'i ve diğer okuyucuları hiciv türünde şiir yazmaktan sakındırır. Çünkü hiciv irfan sahibi insanların meşrebine (mizaç ve tabiatına) keder verir. Eğer insan şairse, sözü güzelliğe sarf etmeli; gücü yeterse halkı büyülemeye çalışmalıdır (Bu konuda daha fazla bilgi ve örnek için bk. Kaplan 2008: 279-288).

Nâbî, bu arada nazım ve nesir ifade biçimlerini de kısaca mukayese eder: Ona göre, nesir şeklindeki söz, çabuk unutulur; ama nazım, ağızdan ağıza dolaşır; vezin ve kafiye cazibesinden ötürü hafızalarda daha kalıcıdır.

$\mathrm{Bu}$ karşılaştırmadan sonra tekrar yergi şiirlerinden bahsetmeye dönen Hayrî-nâme sahibinin hiciv konusundaki diğer düşünce ve tavsiyelerini günümüz Türkçesiyle şu şekilde ifade edebiliriz:

“Hicivden sakınmak gerekir. Çünkü onun sonu uğursuz olur; hiciv yazanlar, insanlar arasında değersiz ve itibarsız sayılır ve kötülenir. Hicve meyledenler ancak sefih, akılsız, beyinsiz kişilerdir. Bu işi akıllı etmez; ahmaklar eder. Hiciv, bencilliğin yoludur ve kötü şöhret kazanmanın vasıtasıdır. Aslında hiciv, şiir kılığında gıybet etmektir. Bundan dolayı günah ve pişmanlığa sebeptir. Hiciv, kat kat kara yüzlülük sebebidir. Onu kim okursa, günahı söyleyene döner. Diyelim ki birisi seni incitmiş, söz ve fiille kalbine üzüntü vermişse, hemen onu hicvetmek ve sefihlerin gittiği yola mı gitmek gerekir? Hicvedilen kişi eğer güçsüzse, onun incinip beddua etmesi yetişir (ulaşır, kâfi gelir); eğer gücü yeterse, intikam almaya çalışır. Onu sen iyilikle kendine bağla; bağışlama ve ikramla utandır. Fena kimselerin ağzını iyilik kapatır. Eğer o kimsenin sana ettiği eziyet sebepsiz ise, mücadele ocağına ateş çalıcı olma! Belki tavır ve davranışlarından pişman olur; sözünden dolayı özür beyan eder. Bu öğüdü sen benden kabul et: Dostluk varken, düşman olma!" 


\section{SONUÇ}

Görüldüğü üzere Nâbî Efendi, başka bazı şairler gibi divanının başında şiir sanatı hakkındaki görüş ve düşüncelerini kısaca yahut uzun uzun anlatma yoluna gitmemiş; ancak telif hayatının sonlarında, 61 yaşında oğlu için yazdığı Hayrî-nâme adlı mesnevisinin vezinli sözün güzelliğiyle alâkalı bölümünde, bu konudaki fikirlerini topluca ifade etmiştir. Onun, başka birçok dîvân sahibi sanatkâr gibi, Türkçe dîvânında çeşitli vesilelerle şiire dair müşahede, kanaat, tesbit, tenkit ve tavsiyelerini dile getirdiği de bilinmektedir. Hayrî-nâme'sinin bütünüyle şiir, nesir, sanat, edebiyat, dil konularına tahsis edilen kısmı ve divanındaki yine aynı meselelerle ilgili manzumeler sayesinde, şairin poetikası hakkında çokça bilgi edinmek mümkün olmaktadır.

Nâbî Efendi, Hayrî-nâme'sinin bahis konusu ettiğimiz bölümünde oğluna ve dolayısıyla diğer okuyuculara vezinli söz, önceki sanatkârların eserlerinin tesiri, okunması gereken Türk, Fars ve Arap şairleri, Arapça bilmenin lüzumu, şiirin hikmetli ve manalı olması lâzım geldiği gibi türlü edebî konular hakkındaki fikirlerini anlatmakta; zaman zaman o mevzulara ait telkin, tavsiye ve temennilerini de dile getirmektedir. Türkçe yazan şairlerden Nef'î ve Bâkî'yi tavsiye eden sanatkârın, Fars ve Arap edebiyatına vukufu dikkat çekici derecededir. O ilim, irfan sahibi, kültürlü bir insana sadece Farsça'nın yetmeyeceğini, İslâmî ilimleri tahsil edebilmek ve Arap şairlerinin eserlerini anlayabilmek için, Arapça öğrenmek de gerektiğini, anılan dillerin bir kuşun iki kanadı mesabesinde olduğunu, tek kanatla uçmanın imkânsızlığını belirtir.

Ruhâ (Urfa)'da doğan, genç yaşta İstanbul'a giderek bu şehirde uzunca bir müddet yaşadıktan sonra Haleb'e yerleşen Nâbî'nin, İstanbul Türkçesine karşı ayrı bir alâka ve sevgisi vardır. O, Halep'te yaşadığı yıllarda İstanbul'un güzelliklerini, halkının zarafetini, güzel ve ince Türkçesini hasretle anmış; İstanbul hanım ve beylerinin zarif ve nükteli konuşma tarzını, mahallî Arapça'dan daha üstün bulduğunu da anlatmıştır.

Nâbî Efendi'nin burada ehemmiyetle ifade ettiği düşüncelerinden biri de şiirin hikmetli ve manalı olması, faydasız ve boş olmaması lâzım geldiğidir. Sanatkâr; şiir ve nesirde hikmeti, gül bahçeleri için su gibi hayatî bir unsur olarak görmektedir. Ona göre şiirlerin, insanlara doğru 
yolu göstermesi için, hikmetli olması gerekir. Şiir sadece mecazın, yani gerçek dışı şeylerin ve beşerî aşk konularının ifade vasıtası olmamalı; hakikat, manaya canlılık vermelidir. Dindar bir insan olduğu bilinen şairin bu düşüncelerinin kaynakları, başka eser veya beyanlarından anlaşıldığı üzere, söz söyleme ve şiirle alâkalı Kur'an ayetleri ve Hz. Muhammed'in hadisleridir.

Nâbî, manasız, yeni bir hayâl ve nükte ihtiva etmeyen, sade, tevriye, teşbih, istiare, cinas gibi edebî sanatların kullanılmadığı şiiri söylenmeye değer bulmaz. Hikmete, hakikat ve manaya ehemmiyet verdiğini gördügümüz usta sanatkâr, umumiyetle sevgilinin güzelliklerinden, içkiden ve tabiat varlıklarından bahseden şairleri "ham" bularak kötüler. Onların gidilmemiş yolda dolaşamadığını ve kestirme olmayan sahalarda gezemediğini belirterek herkesçe bilinen sözlerle geçindiklerini anlatır. Böylece şiirde yeni manaların ifade edilmesi ve alışılmış olanın dışında, yaşanan hayata dayalı konuların işlenmesi gerektiğini dile getirir. Boş ve faydasız şeylerle uğraşmamak lâzım geldiği düşüncesine sahip olan şair, şiir sanatı için mananın ne kadar önemli olduğunu da çeşitli örneklerle anlatır. Ona göre, manasız şiir söylemek, ağını sudan balıksız çekmek gibidir. Manasız söz, kokusuz lâleye, boş bir matla' da özü olmayan bademe benzer. Kısacası, şiirler öyle temiz ve halis olmalıdır ki, onu bir işiten, bin olsun ve bülbül gibi şakısın! "Şiir" dediğimiz sözün manası güzel ve lafzı sağlam olmalı; kalem, "İşte şiir böyle söylenir!.." diye takdir elini yere koymalıdır. Nâbî Efendi, mensur sözün çabuk unutulacağını, ama nazmın ağızdan ağza dolaşacağını belirterek şiirin, nesre göre hafızalarda daha kalıcı olduğunu da edebî görüşlerine ekler. Şair, hicvin mahiyetini anlatarak ve çeşitli zararlarını sayarak oğlunu, dolayısıyla diğer okuyucuları bu tür şiirleri söylemekten sakındırir.

Nâbî'nin şiir, Türk, Fars ve Arap lisanlarıyla edebiyatı hakkında dile getirdiği duygu, düşünce, tenkit ve temenniler, denebilir ki, umumiyetle kendisi gibi bir edebî şahsiyetten beklenebilecek, ondan çıkması yadırganmayacak türdendir. Görüldüğü üzere, şair "Şiirlerin hikmetli olması gerekir ki manası doğru yol göstermeye vesile olsun. Şiir, mutlak mecaz olmasa, hakikat manaya canlılık ve tazelik verse." manasındaki sözleriyle şiirin hikmet ve hakikata dayanması gerektiğine, belirgin bir şekilde dikkat nazarlarını çekmektedir. Onun "ham" sıfatıyla vasıflan- 
dırdığı şairlerin, hemen hemen beşerî aşk, sevgilinin güzellik unsurları, tabiat varlıkları ve içkiden ibaret denebilecek şiirlerine yönelttiği tenkit de bağlı olduğu kültürel değerler yönünden yerinde sayılabilecek bir tesbittir.

Nâbî gibi aslen İstanbullu olmayan ve uzun zaman taşrada yaşayan bir şairin, Türkçe'nin darlığından ve yetersizliğinden şikâyet eden bazı seleflerine rağmen, İstanbul Türkçesinin inceliğini, güzelliğini ve tatlılığını çeşitli vesilelerle ifade etmesi de takdire değerdir. Şair, şiirin manasız, okuyanlar tarafından anlaşılamayacak kadar yabancı kelimelerle dolu ve kavranması güç hayallerle kurulu olanına itiraz etmekte de bizce- haklıdır. Böyle düğümlü, anlaşılamayacak derecede kapalı ve bilinmedik kelimelerle yüklü "şiir"lerin (?) okuyucuyu bu güzel sanattan soğutup uzaklaştıracağı unutulmamalıdır. Nâbî'nin hiciv hakkındaki düşünce ve tavsiyeleri de kabul ve telkin ettiği ahlâk esaslarına uygun olup hayat tecrübelerine dayanmaktadır.

Günümüz ilim adamları, şair ve yazarları, edebiyat tarihimizin Nâbî gibi ileri gelen, değerli şahsiyetlerine alâkasız kalmayıp onlardan çeşitli şekillerde faydalanmasını bilmeli; meselâ söz konusu sanatkârların eserlerinden çağımız okuyucusunun beğenip zevk alabileceği beyitler, mısralar ve parçalar seçmeli; yazdıklarını doğru düzgün biçimde zamanımızın diline çevirmeye gayret etmeli yahut o değerli metinleri tekrar istifadeye açmak için şekil ve üslûp yönünden yenileştirmeye çalışmalıdır.

\section{Kaynaklar}

Abdulkadiroğlu, Abdulkerim ve Nuran Abdulkadiroğlu (1990), Mehmed Âkif Ersoy'un Makaleleri, Ankara: Kültür bakanlığı Yay.

Akyüz, Kenan vd. (1958), Fuzûlî Divamı, Ankara: Türkiye İş Bankası Kültür Yay.

Arslan, Mehmet (1999) Türk Edebiyatında Manzum Surnâmeler: Osmanlı Saray Düğünleri ve Şenlikleri, Ankara: Atatürk Kültür Merkezi Yay.

Bilkan, Ali Fuat (1997), Nâbî Dîvânı, I-II, İstanbul: Millî Eğitim Bakanlığı yayını.

Bilkan, Ali Fuat (1998), Nâbî Hikmet-Şair-Tarih, Ankara: Akçağ Yay.

Bilkan, Ali Fuat (2003) "Nâbî'nin Şiirlerinde Merkez- Taşra Mukayesesi ve İstanbul Sevgisi", Akademik Araştırmalar Dergisi, Sayı 17, s. 179-184. 
Birrî Mehmed Bülbüliyye, Manisa İl Halk Ktp. nr. 5181.

Canım, Rıdvan (2000), Latîfî, Tezkiretü'ş-şu'arâ ve Tabsıratü'n-nuzamâ, Ankara: Atatürk Kültür Merkezi Başkanlı̆̆ı.

Ceyhan, Âdem (2006/1), “Dört Seçkin Dost'un Portresi- Cevrî İbrâhim Çelebi'nin Hilye-i Çihâr-Yâr-i Güzîn'i", Celal Bayar Üniversitesi Sosyal Bilimler Enstitüsü Dergisi, Bahar Sayısı, s. 1-28.

Coşkun, Menderes (2002), Manzum ve Mensur Osmanlı Osmanlı Hac Seyahatnâmeleri ve Nâbînin Tuhfetü'l-Harameyn'i, Ankara: T.C. Kültür Bakanlı̆̆ı yay.

Doğan, Muhammet Nur (2006), Şeyh Galib, Hüsn ü Aşk, İstanbul: Yelkenli Kitabevi.

Durmuş, İsmail (2004), "Methiye”, DİA, XXIX, s. 406-408, Ankara.

Durmuş, İsmail (2005), "Muhammed", DİA, İstanbul, XXX, s. 450-456.

Erkal, Abdulkadir (2009), Divan Şiiri Poetikası, (17. Yüzyıl), Ankara: Birleşik Yay.

Erkan, Mustafa Erkan, (1994), "Dürretü't-tâc", DİA, İstanbul, X, ?.

Erkul, Rasih, (2000) Manisalı Birrî Mehmed Dede, Hayatı, Eserleri, Edebî Şahsiyeti ve Dîvânı, Manisa: Manisa Valiliği Yay.

Gökyay, Orhan Şaik (1974), Keykâvus, Kabusname, trc. Mercimek Ahmet, 3. bs., İstanbul: Millî Eğitim Basımevi.

Hayriyye-i Nâbî, (1292/1875) (Dîvân-ı Nâbî sonunda), İstanbul.

İnce, Adnan (2005), Sâlim Efendi, Tezkiretü'ş-şuarâ, Ankara: Atatürk Kültür Merkezi Başkanlığı.

Kaplan, Mahmut (1995), Hayriyye-i Nâbî, (İnceleme-Metin), Ankara: Atatürk Kültür Merkezi Yay.

Kaplan, Mahmut (2008), "Nâbî'nin Mizah Anlayışı", Prof. Dr. Abdülkadir Karahan'ın Anısına Uluslararası Divân Edebiyatı Sempozyumu, 27-28 May1s 2008, İstanbul, s. 279-288.

Karacan, Turgut (1991), Sabit, Zafername, Sivas: Önder Matbaacılık ve Gazetecilik AŞ.

Karahan, Abdülkadir (1954), İslâm- Türk edebiyatında Kırk Hadis toplama, tercüme ve şerhleri, İstanbul. (2. bs. Ankara 1991).

Karahan, Abdülkadir, (2006) "Nabi", Türkiye Diyanet Vakfi İslâm Ansiklopedisi, c. 32, İstanbul. 
Kocatürk, Vasfi Mahir (1964), Türk Edebiyatı Tarihi, Ankara: Edebiyat Yay. Korkmaz, Seyfullah (2001), "Nâbî'nin Manzum Kırk Hadis Tercümesi", Kayseri ve Yöresi Kültür, Sanat ve Edebiyat Bilgi Şöleni (12-13 Nisan 2001), Bildiriler, c. 1, Kayseri.

Kortantamer, Tunca (1984), "Nâbi'nin Osmanlı İmparatorluğunu Eleştirisi", Tarih İncelemeleri Dergisi, II, İzmir, s. 83-116.

Kortantamer, Tunca (1993), Eski Türk Edebiyatt- Makaleler, Ankara: Akçağ.

Kortantamer, Tunca (2004) Eski Türk Edebiyatt- Makaleler, Ankara: Kültür ve Turizm Bakanlığ 1 Yay.

Levend, Agâh Sırrı (1944), Nabi'nin Surnâmesi, İstanbul: İnkilap Kitabevi.

Mengi, Mine, (1998), “Hayrâbâd", DİA, İstanbul, XVII, s. 54-55. c. 17, İstanbul, s. 54-55.

Muallim Nâcî (1308/1891-92), Esâmî, İstanbul.

Mustafa Nihat (1936), Tükçede Roman Hakkında bir deneme, İstanbul: Remzi Kitabevi.

Müstakimzâde Sâdeddin Süleyman (1255/1839), Şerh-i Dîvân-ı Alî, Bulak.

Necib Âsım (Eylül-Teşrîn-i Evvel 1331/1915), "Hadîs-i Erbaîn Tercümeleri", Millî Tetebbu'lar Mecmuası, c. 2, say1 4, s. 143-165.

Nev 'î-zâde Atâî (1268/1852), Hadâ'iku'l-hakāik fî Tekmileti’ş Şekāik, İstanbul.

Pala, İskender (1989), Şâir Nâbî, Hayriyye, İstanbul: Bedir Yay.

Sevgi, Ahmet (2000), Molla Câmînnin Erba'în'i ve Manzum Türkçe Tercümeleri, Konya.

Şengül, Nedim (2005), Nâbî̀nin Farsça Divançesi, Yüksek Lisans Tezi, Atatürk Üniversitesi Sosyal Bilimler Enstitüsü, Erzurum.

Tolasa, Harun (1986), “18. YY.'da Yazılmış Bir Divan Edebiyatı Terimleri Sözlügüu-Müstakimzâde'nin Istılâhâtü'ş-Şi'rîye'si", İstanbul Üniversitesi Edebiyat Fakültesi Türk Dili ve Edebiyatı Dergisi, İstanbul, c. XXIV-XXV, s. 363-380.

Üzgör, Tahir (1990), Türkçe Dîvân Dîbâceleri, Ankara: Kültür Bakanlığı. Yüksel, Hüseyin (1997), Gazavatnameler ve Nabi'nin Fetihnâme-i Kamaniçe Adlı Eserinin Metni, Dokuz Eylül Üniversitesi Sosyal Bilimler Enstitüsü yüksek lisans tezi.

Zavotçu, Gencay (2007), Türk Edebiyatında Hâb-nâme ve Ömer Fu'âdînin Hâbiyye Risâlesi, Kocaeli: Hazret-i Pîr Şeyh Şa‘bân-1 Velî Vakfı Yay. 